\section{What comes first?}

\author{
An attempt to rework US food-safety \\ regulations will fail without sufficient funds.
}

\section{A} $s$ an example of the absurdity of US food-safety regulations, consider the humble egg. The US Department of Agriculture (USDA) monitors the chickens that produce them and grades the eggs according to their quality. The safety of those (intact) eggs is scrutinized by the Food and Drug Administration (FDA). Once cracked open and used to make a product, the egg comes back under USDA jurisdiction. If that product is then used as an ingredient to make yet another food, responsibility for ensuring its safety again rests with the FDA. Unless, of course, that egg-based food is a meat product then the USDA remains in charge.

US lawmakers waded into this arcane system late last year when they passed the biggest overhaul of the US food-safety system in more than 70 years. The Food Safety Modernization Act, signed into law on 4 January, aims to shore up the FDA side of food-safety regulation, giving the agency expanded authority to conduct inspections and to pull contaminated products from the market. The law also expands the government's role in the prevention of food-borne illnesses, rather than simply reacting to outbreaks on a case-by-case basis. Farms and food manufacturers will now be required to identify potential hazards in their manufacturing process - anything from bacterial contamination to metal screws that could fall off equipment and into food - and develop plans to prevent them.

But by the time President Barack Obama had signed the act, some in the House of Representatives were already threatening to drag the new law into the budgetary battle brewing on Capitol Hill. Critics, who include Representative Jack Kingston (Republican, Georgia), the lead Republican on the subcommittee that oversees the FDA's budget, have threatened to underfund the law. They argue that the cost of the regulations - US $\$ 1.4$ billion over the next five years - outweighs the benefits.

Their sums are short-sighted: the Pew Charitable Trusts in
Washington DC estimates that food-borne illnesses cost the United States $\$ 152$ billion a year, not including the cost to industry in lost sales and lawsuits when outbreaks surface. The investment seems a sound strategy.

It is curious that a bill that won bipartisan support should now face starvation at the hands of an appropriations committee, but it is an old story for the FDA. Famously overstretched, the agency's budget has failed to keep pace with the expansion of its mandate.

Without adequate funding for inspectors, the food-safety law will have no teeth. The new law also calls for funds to sponsor food-safety research. In the absence of that money, the underfunded and overextended National Institute of Food and Agriculture shoulders the bulk of such projects. That institute faces
"It is curious that a bill that won bipartisan support should now face starvation at the hands of an appropriations committee." a budget crisis of its own: its competitive research grants programme is authorized to receive $\$ 700$ million. It got $\$ 262$ million in 2010, and its budget in 2011 is uncertain.

Meanwhile, improving food safety is not only a question of money. As is often the case between government agencies, communication between the FDA and the USDA is notoriously lacking. Last September, for example, The Wall Street Journal reported that USDA inspectors noted filthy conditions at Wright County Egg, a huge producer in Galt, Iowa, when they arrived to grade its eggs, but failed to inform the FDA about the possible food-safety risk. A Salmonella outbreak leading to the recall of hundreds of millions of eggs was later traced back to that farm, as well as to another.

The barriers to better communication are clearly surmountable: in 1995, the FDA, USDA and the US Centers for Disease Control and Prevention in Atlanta, Georgia, worked together to create PulseNet, a contaminant alert system that tracks the genetic fingerprints of bacteria found in food. The programme alerts officials when the incidence of any one bacterial strain rises above background levels. PulseNet allowed regulators to track down the spinach behind a 2006 outbreak of Escherichia coli O157:H7 food poisoning that made more than 200 people ill. The programme has attracted international collaborators as well. It is a food-safety success story made possible by careful coordination among agencies, and it is a story worth chewing over.

\section{Staring at the Sun}

$\mathrm{H}$ umankind has long marvelled at the Sun and basked in its warmth. So it may be disconcerting to learn that the Sun is not quite as bright as we thought - it now seems that our star gives off $0.34 \%$ less radiation than was previously estimated (G. Kopp and J. L. Lean Geophys. Res. Lett. 38, L01706; 2011).

Total solar irradiance, a measure of the Sun's cumulative energy output, is a fundamental, if little-appreciated, number in Earth science. It acts as a baseline for our calculations on climate, and accounts for almost half of our planet's energy balance with impressive simplicity. (It is on the other half of the equation, concerning what happens to that energy once it enters the system, that things get complicated.) The new value should not make calculations trickier: equations representing clouds, for instance, come with enough uncertainty to absorb the effect. But it is important to have an accurate picture of the Sun's output.

Measurements of the Sun from space began in November 1978, and the subsequent continuous record has proved invaluable to the study of solar cycles and the impact of solar variation on the climate system.
Next month, NASA will launch the Glory spacecraft to bolster and extend that record over the coming years (see page 457).

Glory's measurements of the Sun could be the most accurate so far, and they should be the first to match earlier measurements - from NASA's Solar Radiation and Climate Experiment — without adjustment. Indeed, solar researchers are now working to calibrate their systems against an absolute standard before launch, which would make it easier to work with different instrument designs.

The solar physicists who are doing this work have two fears. The first is that the continuous record of solar irradiance measurements will one day come to an end. With the Swiss sensor PREMOS in the air launched last June on the French satellite PICARD - and Glory on the way, the outlook is bright over the next few years. But so far, only the United States has proposed a follow-on mission, scheduled for 2014.

Physicists' second fear boils down to a moral hazard. Part of the rationale behind the search for an absolute standard is to make the data record resilient enough to withstand future gaps in measurement. But if funders know that the technology has improved to that point, why should they approve missions to plug the gaps? We are not there yet; instrument-makers have yet to prove that their toys are as
DNATURE.COM To comment online, click on Editorials at: go.nature.com/xhunqv precise, robust and predictable as they claim. But a future where these crucial data are accurate enough to stand on their own, independently of the data record, should be pursued, not feared. $\square$ 